\title{
Implementation of Guided Inquiry Learning Model to Improve Understanding Physics Concepts and Critical Thinking Skill of Vocational High School Students
}

\author{
Johar Maknun $^{1}$ \\ ${ }^{1}$ Faculty of Technology and Vocational Education, Universitas Pendidikan Indonesia, Bandung, Indonesia \\ Correspondence: Johar Maknun, Faculty of Technology and Vocational Education, Universitas Pendidikan \\ Indonesia. Jl. Dr. Setiabudhi No. 229 Bandung 40154, West Java, Indonesia.
}

Received: January 31, 2020

Accepted: March 4, $2020 \quad$ Online Published: May 27, 2020

doi:10.5539/ies.v13n6p117

URL: https://doi.org/10.5539/ies.v13n6p117

\begin{abstract}
This research aims to implement the guided inquiry learning model to improve the understanding of concepts and critical thinking skills of Vocational High School (SMK) students. The quasi-experiment method with the randomized pretest-posttest control group design was used to obtain data from students of one of the Vocational High Schools (SMK) in Bandung, West Java, Indonesia. The sample consisted of 28 experiment and control class students that carried out a guided inquiry and conventional learning, respectively. The result shows an average increase in understanding of physics concepts and critical thinking skills of the experimental class by 0.71 (high category) and the control class by 0.28 (low category). Based on the average test results using the independent sample t-test method, the understanding of physics concepts and the critical thinking skills of the experimental class was eminent to the control class. Furthermore, the research instruments were tests of understanding concepts and critical thinking skills with an average increase of 0.71 in the high category and 0.28 in the low category, respectively. The result showed that the implementation of guided inquiry learning models has the ability to significantly improve the understanding of static fluid concepts and critical thinking skills of Vocational High School students compared to conventional learning. This was because it provided the opportunity for students to independently construct a concept through problem presentation, formulation of hypotheses, data collection, analysis, and conclusions.
\end{abstract}

Keywords: concept understanding, critical thinking skills, inquiry learning

\section{Introduction}

\subsection{Background of the Study}

Learning is defined as an effort by teachers to help students carry out educational activities. Its implementation is the core of organizing education through learning plans made by the teacher, which are realized through effective and efficient activities in accordance with the characteristics of the lesson, therefore this study analyzes Physics in Vocational High Schools (SMK).

The study of physics naturally varies from their phenomena, causes, consequences, and uses. Studying the subject means solving and discovering why and how phenomena occur. It is an empirical science, which means that everything learned in physics is based on observations on nature and its symptoms (Sears \& Zemasky, 2004). In addition, its numerous inventions form the basis of modern industry and technology, such as computers, transportation, communication, health, etc. (Tipler \& Mosca, 2007). According to Alonso and Finn (1992), physics is a quantitative science that uses mathematics in expressing ideas. It is distinguished from other sciences with a very high level of abstraction and idealization (Thomas, 2013). Physics is also a basic science used to understand applied science, which is the basis of technological development. As a component in the curriculum, its lessons are meaningful in fostering the intellectual, attitudes, interests, skills, creativity, and critical thinking abilities.

Physics subjects in Vocational High Schools aims at achieving the following (a) Form a positive attitude on students towards the subject by realizing the order and beauty of nature and glorify the greatness of God Almighty,

(b) Cultivate a scientific attitude of honesty, objectivity, openness, resilient, critical and ability to work with others,

(c) Develop experience in formulating problems, propose and test hypotheses through experiments, design and 
assemble experimental instruments, collect, process and interpret data, as well as communicate experimental results verbally and in writing, (d) Develop the ability to think inductively and deductively by using the physical concepts and principles to explain various natural phenomena and solve problems qualitatively and quantitatively, (e) Master the concept of physics and have the skills to develop knowledge and self-confidence as a provision to continue education at a higher level for the development of science and technology (Ministry of Education and Culture/Kemendikbud, 2015).

Based on observations in several Vocational High Schools in Bandung City, West Java Province, Indonesia, the physics learning carried out is informative. This is because students acquire concepts from teachers through mathematical equations and calculations. Therefore, they tend to have difficulty and are not accustomed to understanding its concept and relationship to natural phenomena (Marwiah, 2014). The current learning strategy has not been able to achieve the objectives of physics lessons fully, therefore, innovations are needed. This is in line with the opinion of Redish et al. (1998), which stated that learning physics has traditionally not helped students in developing scientific attitudes and in understanding its concepts.

Students' perceptions of physics lessons vary, some learn by memorizing formulas and problem-solving algorithms, while others believe that learning involves more conceptual development in understanding. Furthermore, some students believe that physics is not connected to the real world, while others are of the opinion that the idea learned is relevant and useful in a variety of real contexts (Sahin, 2010). Therefore, various learning methods are needed to serve the students' varying perceptions.

Physics learning methods need to refer to its nature. Therefore, learning is carried out using scientific methods though observations, inquiries, and information collection that has been obtained and communicate the results. This is in line with the opinion of Adamčíková and Tarábek (2010), which stated that an important element of learning physics is to understand and communicate the concepts as well as steps of the experiment. Suparno (2013) stated that students need to actively construct their knowledge by processing material, digesting, thinking, analyzing, and understanding.

Therefore, the inquiry learning method is applied as a solution to learning the nature of physics in Vocational High Schools. This technique was first developed by Richard Suchman in 1962 to teach students the process of researching and explaining foreign phenomena (Joyce et al., 2000). The inquiry is a learning process that maximally involves all students' abilities to search and investigate systematically, critically, logically, and analytically, in order to formulate their findings with confidence (Gulo, 2008). This technique is very important in the formation of science and has the ability to maximize students' scientific knowledge and understanding (Ozdilek \& Bulunuz, 2009).

It is divided into three types, guided, free, and modified inquiries (Jauhar, 2011). However, the guided free inquiry was utilized in this study due to its ability to be adjusted to the problem. Students are not accustomed to inquiry learning therefore, they need a lot of guidance from the teacher in implementing this new technique.

Guided inquiry is a learning model that trains students' skills in carrying out the investigation process, which enables them to collect data, process it, and build conclusions independently in order to answer questions asked by the teacher (Maguire et al., 2010). The guided inquiry learning model trains students to build answers and think intelligently in determining various alternative solutions to problems asked by teachers, develop concept understanding skills, build a sense of individual responsibility, and train the process of delivering the analyzed concepts (National Research Council (NRC), 2012).

Reform efforts in the field of education and learning at all levels include developing the higher-order thinking skills needed to face life and win the competition in the era of globalization. Zoller et al. (2000) stated that applied learning needs to focus on teaching higher-order thinking skills, which is a cognition process, based on the mental ability to acquire knowledge and improve the quality of education to improve the quality of education. Based on this process, it is grouped into basic (rational) and complex thinking (higher-order). Basic thinking includes memorizing, imagining, grouping, generalizing, comparing, evaluating, analyzing, synthesizing, deducing, and creating inference. While the complex thinking process consists of problem-solving, decision making, critical and creative thinking processes (Costa, 1985). Critical thinking is reflective, which is based on the reasoning that is focused on determining what needs to be believed and carried out (Ennis, 1985).

According to Kalman (2002), critical thinking is a process that allows students to gain new knowledge through problem solving and collaboration. It is the various strategies that increase the likelihood of desired outcomes. Furthermore, it involves various activities such as analyzing, synthesizing, making judgments, creating, and applying new knowledge to real-world situations. Critical thinking is important in the learning process because it provides opportunities for students to learn through discovery, which makes them responsible for their learning 
(Walker, 1998).

Furthermore, critical thinking is a skill that students need to possess to face life in the family, school, and community. Students with the ability to think critically tend to plan and solve problems systematically; therefore, it is widely known as a valuable skill in everyday life (Verlinden, 2005). Indicators of critical thinking skills are arranged systematically to build students' knowledge during the learning process (Putri \& Istiono, 2017). Critical thinking is very necessary for the current era of science and technology development because it also raises several problems for humans and the environment.

\subsection{The Research Questions}

The research questions were addressed as follows:

a. How is the impact of guided inquiry learning on fostering physics concept's comprehension in Vocational high school students?

b. How is the impact of guided inquiry learning on promoting vocational high school students' critical thinking skill?

\subsection{The Guided Inquiry Learning Model}

Inquiry learning is rooted in a constructivism approach to help students build knowledge like scientists (Tseng et al., 2013). Sund and Trowbridge (1973) stated that in the guided inquiry learning model, the teacher provides extensive guidance for students. This is usually in the form of questions that lead students to determine a concept through inquiry activities, thereby enabling them to participate in the learning properly. Furthermore, Kulthau et al. (2007) reported that guided inquiry is a carefully structured plan, where learning objectives are carefully monitored through teacher intervention. In addition, students are guided till they gain in-depth knowledge and understanding of the lesson therefore, they slowly learn independently.

Based on the above description, it is seen that the main task of the teacher in guided inquiry learning is to provide an environment that facilitates students to explore and construct knowledge through interactions with friends and teachers. During implementation, the teacher provides guidance, instructions, and planning. Therefore, students tend to gain in-depth knowledge and understanding of the subject.

Spiro and Knisely (2008) developed a guided inquiry learning design that was systematic with clear stages as follows:

Stage 1: Observing and generalizing questions.

Students are provided with a phenomenon or problem to be observed and identified, then based on the obtained information, and they generalize a question to discuss its solution.

Stage 2: Making a hypothesis.

The teacher provides opportunities for students to express hypotheses and guides them to determine and prioritize the relevant inquiry. Hypotheses are temporary answers to questions or problem solutions that are tested with data.

Stage 3: Designing the experiment.

The teacher provides the opportunity for students to determine the steps of the experiment to test the hypothesis. This is conducted through group discussions. Furthermore, they are asked to mention the variables contained in the experiment. The variables are divided into "already known" and " not known" with predictions developed for proper analysis. In order to facilitate the preparation of the experimental steps and the prediction process, students are provided with a series of tools and materials.

Stage 4: Conducting an experiment to obtain information.

Students conduct experiments in accordance with the steps that are arranged to obtain relevant information regarding the initial hypothesis. They are responsible for testing the hypotheses that are formulated by analyzing the data obtained. An important factor in conducting a hypothesis test is 'true' and 'false' thinking. After obtaining conclusions from experimental data, students test the formulated hypotheses to determine whether it is accepted or rejected.

Stage 5: Analyzing data and experiment reports.

The final stage of guided inquiry learning is to make temporary conclusions based on the data obtained. The teacher provides an opportunity for each group to convey the results obtained by processing the collected data and guides them in making an experiment report. 


\subsection{Understanding of Physics Concepts}

According to Johnson (2000), understanding is the ability to explain utilized strategies. While the concept is a general idea agreed by scientists, and which arises due to the ability of someone to distinguish, and group concepts from others, based on certain characteristics. Dahar (1996), explained several characteristics of the concept, namely (1) It is a thought that is owned by a person or group of people, (2) It arises as a result of human experience with more than one event or fact, (3) It is the result of abstract human thinking that encapsulates many experiences, (4) Concepts are the linking or patterning of facts, (5) It is considered inappropriate due to the emergence of new facts, and therefore the relevant concept needs to undergo changes.

Based on the above definition and understanding, it is concluded that concept is the ability of students to explain a definition, special characteristics, essence, core and content using their words, without changing its meaning. Students tend to understand the concept based on their interpretation. This ability is very important because, without proper understanding, it becomes impossible to solve small problems properly.

The term "comprehension" has been changed to "understanding," due to the expansion of Bloom's taxonomy. According to Anderson and Krathwohl (2001), Bloom's taxonomy in accordance with understanding consists of the following:

a. Interpretation, which occurs when students are able to change information from one form to another. For example, pictures become words, numbers become words, and vice versa.

b. Exemplification: This occurs when students are able to provide examples of general concepts or principles. This includes the process of identifying the main features of a general concept or principle to select or make examples.

c. Classification: This occurs when students know that something (a particular example or event) belongs to a certain category (e.g., concepts or principles). It involves finding relevant features or patterns, which are compatible with specific examples and general concepts or principles.

d. Summarization: This occurs when students are able to express one sentence that represents information received or abstracts theme. It involves the process of making a summary of the information.

e. Inference: This occurs when students are able to abstract a concept or principle that consists of a series of examples or events by drawing connections.

f. Comparing: This is the cognitive process that involves the process of detecting similarities and differences between two or more objects, events, ideas, problems, or situations. Comparing determines the relationship between two ideas, objects, etc.

g. Explanation: This occurs when students are able to build and use a causal model of a system. This model is derived from theory or based on the results of research or experience. A complete explanation includes the process of making a causal model, which includes every major part of a system and the process of using a model to determine changes in one part of a system of relationships in a series that affect changes in this section.

\subsection{Critical Thinking Skills}

Critical thinking skill involves the ability to clearly and precisely raise vital questions, gather relevant information, reach well-reasoned conclusions, make accurate decisions, assess the credibility of sources, identify the cause that effect relationships, and effectively communicate with others in figuring out solutions (Ennis, 1989). Furthermore, Tiruneh et al. (2017) stated that critical thinking skills involve the ability to draw valid conclusions, identify relationships, analyze probabilities, make predictions and logical decisions, and solve complex problems.

A study of students' critical thinking skills revealed that it does not develop without explicitly and intentionally implanted efforts (Zohar, 1994). Students are unable to properly develop critical thinking skills without being challenged to practice using them in learning. Students are not naturally born to think critically, and this skill is acquired through the help of teachers. Critical thinking is an ability that is learned therefore it needs to be taught.

Students' critical thinking skills need to be measured with an appropriate test measurement tool. According to Tiruneh et al. (2016), it needs to be linked to indicators and everyday problem-solving. The selection of the critical thinking skills developed was related to the concept of physics. This is in line with the meta-analysis conducted by Abrami et al. (2015). Furthermore, Ennis (1985) stated that there are 12 indicators of critical thinking skills in 5 groups, as shown in (see Table 1). 
Table 1. Indicators of critical thinking skills according to Ennis

\begin{tabular}{ll}
\hline Critical Thinking Skills & Critical Thinking Skills Sub \\
1. Providing elementary clarification & $\begin{array}{l}\text { focusing the question } \\
\text { analyzing the argumentation } \\
\text { asking and answering clarifying and challenging questions }\end{array}$ \\
\hline 2. Building basic support & $\begin{array}{l}\text { considering credibility (criteria of a source) } \\
\text { observing and considering the results of the observations }\end{array}$ \\
\hline 3. Inference & $\begin{array}{l}\text { making deductions and considering the results } \\
\text { making and considering induction } \\
\text { making and considering the value of the decision }\end{array}$ \\
\hline 4. Making advanced clarification & $\begin{array}{l}\text { defining terms } \\
\text { identifying assumptions }\end{array}$ \\
\hline 5. Strategies and tactics & $\begin{array}{l}\text { deciding on an action } \\
\text { interacting with other people }\end{array}$ \\
\hline
\end{tabular}

Source: Ennis (in Costa, 1985).

The understanding of physics concepts requires thinking and reasoning in order to solve its problems. Mastery of physics material requires basic, complex, and critical thinking skills (Novak \& Gowin, 1985). Critical thinking is logical and reflective that is centered on what decisions are believed or conducted (Ennis, 1985). It needs to be developed in students because they easily understand concepts, and are sensitive to problems.

\section{Method}

\subsection{Research Design}

The quasi-experimental method was used to obtain a picture of the increasing understanding of concepts and critical thinking skills of Vocational High School (SMK) students that implemented guided inquiry and conventional learning. While the research design used was the randomized pretest-posttest control groups (Fraenkel and Wallen, 2007). The shape of the design is shown in (see Table 2).

Table 2. Research Design

\begin{tabular}{cccc}
\hline Class & Pretest & Treatment & Posttest \\
\hline Experiment & $\mathrm{O}$ & $\mathrm{X}$ & $\mathrm{O}$ \\
\hline Control & $\mathrm{O}$ & $\mathrm{Y}$ & $\mathrm{O}$ \\
\hline
\end{tabular}

Description: $\mathrm{X}$ : treatment in the form of guided inquiry learning models; $\mathrm{Y}$ : treatment in the form of conventional learning models; O: pretest and posttest.

\subsection{The Sample}

This research was conducted in one of the Vocational High Schools (SMK) in Bandung, West Java, Indonesia. The subjects of this study were the experiment and control classes with 28 students each, thereby culminating in 56 students.

\subsection{The Instrument}

The instrument used is as follows:

a. The concept understanding test consists of 20 multiple choice questions for static fluid material, which consists of the concepts of hydrostatic pressure, Pascal, and Archimedes' laws. It also consists of indicators used to understand the test concept, such as interpreting, exemplifying, inferring, comparing, and explaining.

b. The critical thinking skills test consists of 20 multiple choice questions in accordance with the Ennis's (1985) indicators, such as elementary and advanced clarification, basic support, inference, and strategies as well as tactics.

The technique for scoring multiple-choice questions was given a dichotomous score, with 1 and 0 for the correct and wrong answers, respectively (Fang et al., 2016). 


\subsection{The Analysis Data}

The analysis associated with increasing students' understanding of the concepts and critical thinking skills used normalized gain scores. This is calculated using the normalized gain score formula formulas follows (see Table 3):

$$
\mathrm{N}-\text { gain }=\frac{\mathrm{S}_{\text {post }}-\mathrm{S}_{\text {pre }}}{\mathrm{S}_{\max }-\mathrm{S}_{\text {pre }}}
$$

Description:

$\mathrm{S}_{\text {post }}=$ posttest score

$\mathrm{S}_{\text {pre }}=$ pretest score

$\mathrm{S}_{\text {max }}=$ ideal maximum score

Table 3. N-gain categories

Source: Hake (1998).

\begin{tabular}{cc}
\hline Category & Rata-rata N-gain \\
\hline Low & $0.7 \leq<\mathrm{g}>\leq 1$ \\
\hline Moderate & $0.3 \leq<\mathrm{g}><0.7$ \\
\hline High & $<\mathrm{g}><0,3$ \\
\hline
\end{tabular}

Independent sample t-test was performed to examine the difference in average of the concepts of physics understanding and critical thinking skills between the experimental group and the control group. SPSS version 16 was used as a counting appliance.

\section{Results}

\subsection{The Implementation of Guided Inquiry Learning}

The implementation of guided inquiry learning on this research described as follows:

Stage 1: Observing and generalizing questions.

- The teacher demonstrates the phenomenon of hydrostatic pressure and the affect factors.

- Students illustrates the phenomenon of water-filled tubes they see in the form of images and verbally.

- The teacher presents other example and analogy of static fluid.

- Students construct the questions to investigate the influence of fluid depth on pressure.

Stage 2: Making a hypothesis.

- Students formulate a hypothesis based on hydrostatic pressure.

- The teacher supervises students to specify the relevant hypotheses and determine the priority hypotesis for testing.

Stage 3: Designing the experiment.

- Students contrived qualitative and quantitative data collection plans as well as execute their plans based on those results of water-filled tube observations.

- The teacher leads students to arrange experiments suitable for testing the hydrostatic pressure concept.

Stage 4: Conducting an experiment to obtain information.

- The teacher leads students to acquire information through experiment.

- Students perform experiments to test the hydrostatic pressure concept.

- The teacher leads students to create mathematical formulas and graphs on hydrostatic pressure.

- Students provide an explanation of the hydrostatic pressure phenomeon using text, mathematical, and graphical formats.

Stage 5: Analyzing data and experiment reports.

- The teacher directs students to make hydrostatic pressure prediction at each point of liquid's depth.

- Students produce mathematical and graphical analysis based on observation's results. 
- Students throw the conclusions regarding the hydrostatic pressure at different depths.

- The teacher provides opportunities for students to apply the conclusions obtained in other circumstances.

\subsection{Understanding of Physics Concepts}

The first objective of this study was to describe the conceptual understanding of Vocational High School (SMK) students that received learning with the guided inquiry model (experiment class) and conventional learning (control class). Data were obtained through concept understanding tests, which were conducted at the beginning (pretest) and the end (posttest) of the research. A description of the conceptual understanding of each indicator is shown in Figure 1.

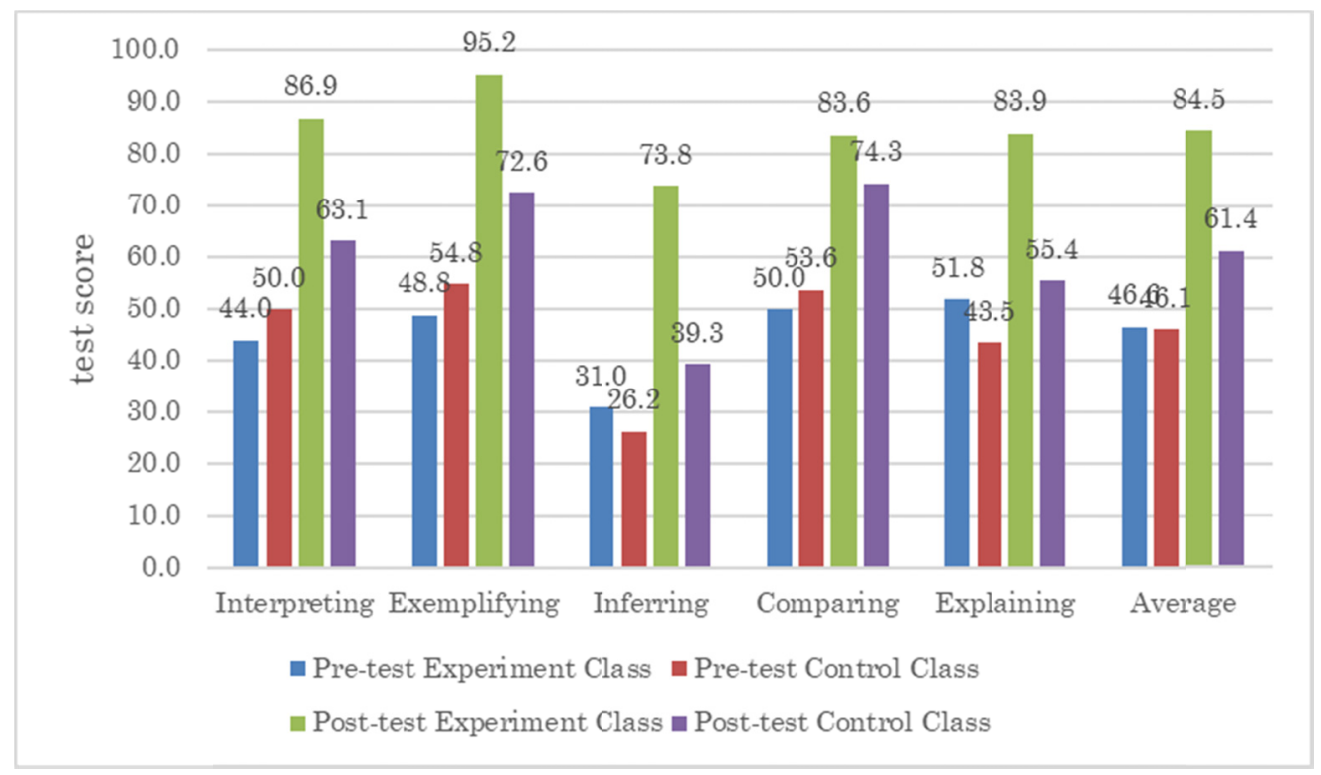

Figure 1. Description of understanding of physics concepts of vocational students

Based on the results of the study presented in Figure 1, it showed that the average pretest scores of the experiment and control classes were not significantly different. Therefore, there were no differences in initial ability between the experiment and control classes. This was because, in general, the concept of static fluid had been studied by students at the junior high school. After determining their initial abilities in both classes, learning was continued on the concept of static fluid using different treatments. The experimental class obtained guided inquiry learning, while the control obtained conventional learning.

Guided inquiry learning was carried out at the beginning, where students observed and generalized problems that they often encountered in daily life. Through these, they were required to submit, test, and carry out experiments on proposed hypotheses, followed by analyzing the experimental data and drawing conclusions. Therefore, students have the ability to actively construct static fluid concepts independently under the guidance and instructions of the teacher. Conventional learning began with an explanation of the concept of static fluid by the teacher through lectures, and answer activities, which then ended with the completion of mathematical questions.

\subsection{Critical Thinking Skills}

The second objective of this research was to describe the improvement in critical thinking skills of Vocational High School students that obtained guided inquiry learning (experiment class) and conventional learning (control class). Critical thinking skills data were obtained through tests based on the physics concept of static fluid material, which was conducted at the beginning (pretest) and the end (posttest). Its description for each indicator is based on the pretest and posttest results, as shown in Figure 2. 


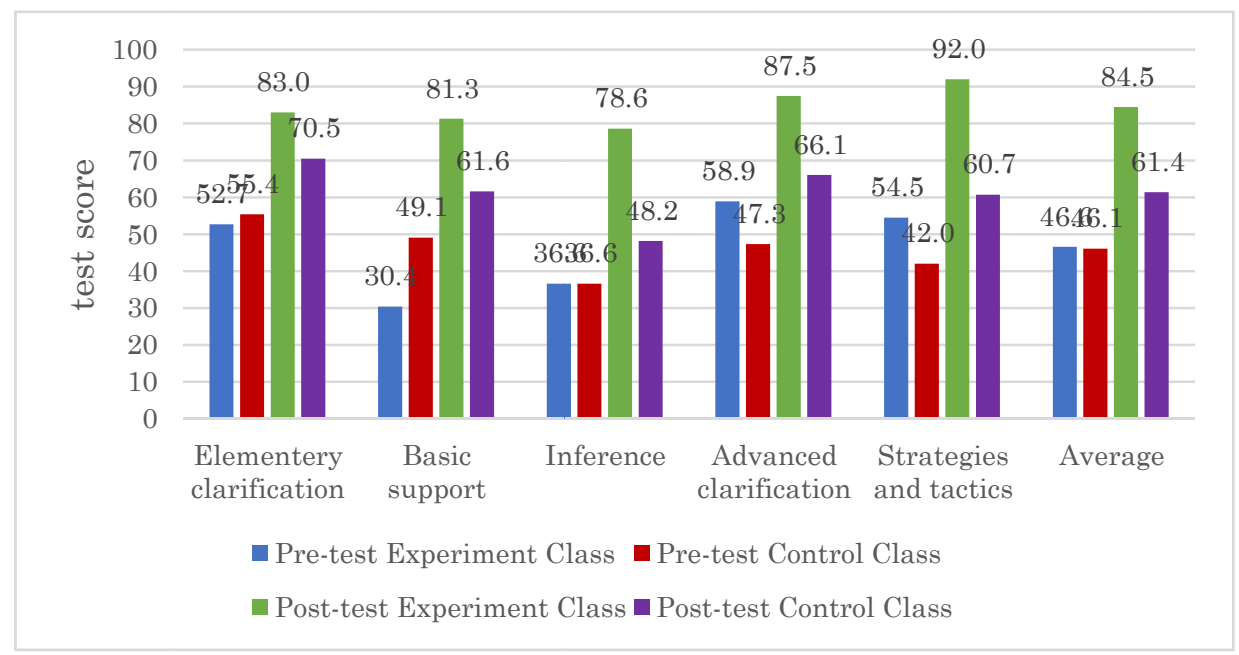

Figure 2. Description of critical thinking skills of vocational students

Based on the data in Figure 2, the average pretest score in experiment and control classes were 46.6, and 46.1, respectively. While the average posttest score in the experiment and control classes were 84.5 and 61.4 , respectively.

\section{Discussion}

\subsection{Increased Understanding of Physics Concepts}

The stages of learning undertaken by students in the two classes were different, but the average understanding scores of static fluid concepts were equally increased when compared with the pretest. The results of data analysis of posttest scores associated with understanding showed that the static fluid concept of students that learned through the guided inquiry models was better than those with conventional learning. An increase in the mastery of physics concepts of vocational students was shown by the value of N-gain. Furthermore, the N-gain scores of conceptual understanding in the experiment and the control classes are shown in Figure 3.

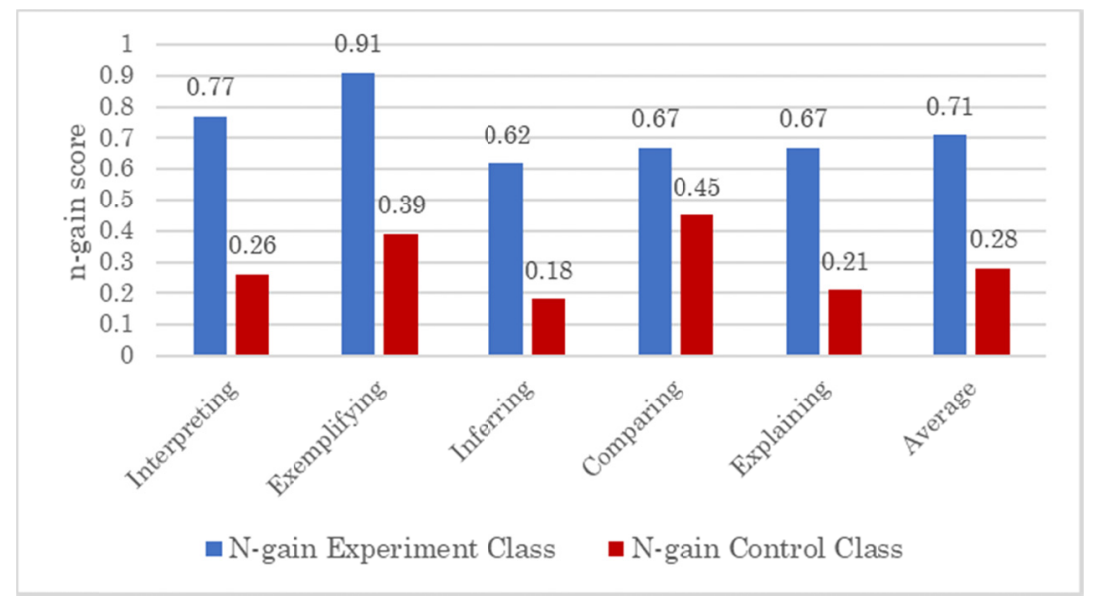

Figure 3. N-gain mastery of the physics concepts of vocational students

Based on Figure 3, it is seen that the average N-Gain score for each indicator in the experiment class was higher than the control. The highest increase in the experiment and control classes occurred in the exemplifying indicator of 0.91 and comparator of 0.45 , respectively. While the lowest increase in the experiment and control classes occurred in the inferring indicator of 0.62 and 0.18 , respectively.

The success of the guided inquiry learning model compared to conventional learning in improving understanding of concepts is separated from the learning process that was passed by students. Guided inquiry learning facilitated 
students to be more active in the following learning and building new knowledge, through problem-solving activities, formulating hypotheses, collecting and analyzing data, as well as conclusion. Therefore, the knowledge obtained by students is more meaningful, easy to remember, and applied correctly in solving problems. This is in accordance with the opinion of Bruner (Dahar, 1996) which stated it is in human nature to always seek knowledge actively, therefore, the subject matter obtained by students is more durable, easy to remember, implementable in different conditions, as well as motivate and train the thinking skills of students.

Independent sample t-test method was used to test the difference in average scores in the control class and the experimental class to measure the superiority of guided inquiry learning in improving understanding of physics concepts. The test results are listed in Table 4.

Table 4. Average difference test results in the physics concepts understanding in experimental class and control class

\begin{tabular}{|c|c|c|c|c|c|c|c|c|c|}
\hline & \multirow{4}{*}{ Pairs } & \multicolumn{8}{|c|}{ Statistics } \\
\hline & & \multicolumn{5}{|c|}{ Paired Differences } & \multirow{3}{*}{$\mathrm{t}$} & \multirow{3}{*}{$\mathrm{df}$} & \multirow{3}{*}{$\begin{array}{c}\text { Sig. } \\
\text { (2-tailed) }\end{array}$} \\
\hline & & \multirow[t]{2}{*}{ Mean } & \multirow{2}{*}{$\begin{array}{c}\text { Std. } \\
\text { Deviation }\end{array}$} & \multirow{2}{*}{$\begin{array}{l}\text { Std. Error } \\
\text { Mean }\end{array}$} & \multicolumn{2}{|c|}{$\begin{array}{c}95 \% \text { Confidence Interval of } \\
\text { the Difference }\end{array}$} & & & \\
\hline & & & & & Lower & Upper & & & \\
\hline 1 & $\begin{array}{l}\text { Post test Understanding } \\
\text { Experiment Class - Post test } \\
\text { Understanding Control Class }\end{array}$ & 4.60714 & 3.05916 & .57813 & 3.42092 & 5.79336 & 7.969 & 27 & .000 \\
\hline 2 & $\begin{array}{c}\text { Post test Understanding } \\
\text { Experiment Class (Interpreting) - } \\
\text { Post test Understanding Control } \\
\text { Class (interpreting) }\end{array}$ & .71429 & 1.04906 & .19825 & .30750 & 1.12107 & 3.603 & 27 & .001 \\
\hline 3 & $\begin{array}{l}\text { Post test Understanding } \\
\text { Experiment Class (Exemplifying) } \\
\text { - Post test Understanding Control } \\
\text { Class (Exemplifying) }\end{array}$ & .67857 & .86297 & .16309 & .34395 & 1.01319 & 4.161 & 27 & .000 \\
\hline 4 & $\begin{array}{l}\text { Post test Understanding } \\
\text { Experiment Class (Infering) - Post } \\
\text { test Understanding Control Class } \\
\text { (Infering) }\end{array}$ & 1.03571 & .92224 & .17429 & .67811 & 1.39332 & 5.943 & 27 & .000 \\
\hline 5 & $\begin{array}{l}\text { Post test Understanding } \\
\text { Experiment Class (Comparing) - } \\
\text { Post test Understanding Control } \\
\text { Class (Comparing) }\end{array}$ & .46429 & 1.26146 & .23839 & -.02486 & .95343 & 1.948 & 27 & .062 \\
\hline 6 & $\begin{array}{l}\text { Post test Understanding } \\
\text { Experiment Class (Explaining) - } \\
\text { Post test Understanding Control } \\
\text { Class (Explaining) }\end{array}$ & 1.71429 & 1.35693 & .25644 & 1.18812 & 2.24045 & 6.685 & 27 & .000 \\
\hline
\end{tabular}

According to the test results in table 4, students' understanding of physics concepts average was higher in those who perform guided inquiry learning compared to those who practice conventional learning model. Furthermore, students who conduct guided inquiry learning were have a higher understanding of physics concepts than those who performed conventional learning in the aspect of interpreting, exemplifying, inferring and explaining. Meanwhile, there was no understanding of physics concepts disparity in concepts comparing both on students who conduct guided inquiry learning and conventional learning.

The average improvement of conceptual understanding in the experiment class was 0.71 , the high category, and 0.28 in the control class in the low category. The results of testing the average N-gain score of students in both classes showed that the implementation of guided inquiry learning models tends to further enhance students' understanding of concepts compared to conventional learning. The increase is used to carry out a science-based inquiry, which has the potential to promote students' conceptual understanding (Crawford, 2007; Minner et al., 2010). This finding is in accordance with Sopamena's (2009) research, which stated that the implementation of guided inquiry learning models improves students' understanding of concepts with an average N-gain score of 0.72 
in the high category.

\subsection{Increased Critical Thinking Skills}

Increased critical thinking skills of vocational students were shown by the value of $\mathrm{N}$-gain as listed in the graphic below.

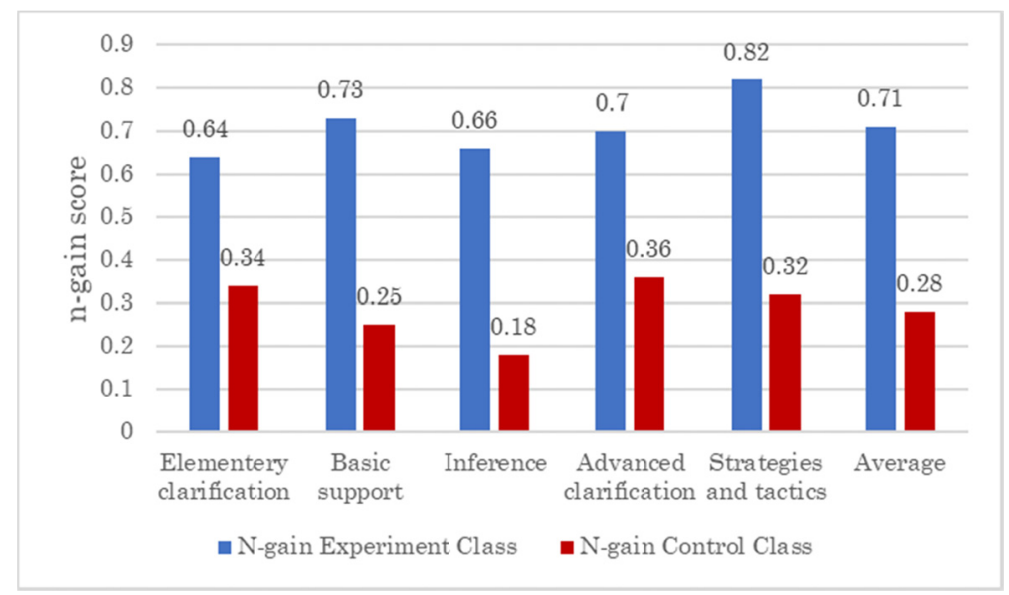

Figure 4. N-gain critical thinking skills of vocational students

Figure 4 showed the highest $\mathrm{N}$-gain of the experimental class on the strategies and tactics indicator was 0.82 , while the lowest on the elementary clarification indicator was 0.64 . For the control class, the highest N-gain in the advanced clarification indicator was 0.36 , while the lowest in the inference indicator was 0.18 . The average acquisition of $\mathrm{N}$-gain for the experiment class was 0.71 , which was included in the high category, and the control class was 0.28 in the low category. Based on these data, the average $\mathrm{N}$-gain of the experiment class was higher than the control.

Independent sample t-test method was used to test the difference in average scores in the control class and the In order to reveal the superiority of guided inquiry learning in fostering the critical thinking skills, independent sample t-test was conducted to measure the average of differences between experiment class and control class. The test results are listed in Table 5.

Table 5. Average difference test results in the critical thinking skills in experimental class and control class

\begin{tabular}{|c|c|c|c|c|c|c|c|c|c|}
\hline & \multirow{4}{*}{ Pairs } & \multicolumn{8}{|c|}{ Statistics } \\
\hline & & \multicolumn{5}{|c|}{ Paired Differences } & \multirow{3}{*}{$\mathrm{t}$} & \multirow{3}{*}{$\mathrm{df}$} & \multirow{3}{*}{$\begin{array}{c}\text { Sig. } \\
\text { (2-tailed) }\end{array}$} \\
\hline & & \multirow[t]{2}{*}{ Mean } & \multirow{2}{*}{$\begin{array}{c}\text { Std. } \\
\text { Deviation }\end{array}$} & \multirow{2}{*}{$\begin{array}{l}\text { Std. Error } \\
\text { Mean }\end{array}$} & \multicolumn{2}{|c|}{$\begin{array}{c}95 \% \text { Confidence Interval of } \\
\text { the Difference }\end{array}$} & & & \\
\hline & & & & & Lower & Upper & & & \\
\hline 1 & $\begin{array}{c}\text { Post test Critical Thinking } \\
\text { Experiment Class - Post test } \\
\text { Critical Thinking Control Class }\end{array}$ & 4.60714 & 3.05916 & .57813 & 3.42092 & 5.79336 & 7.969 & 27 & .000 \\
\hline 2 & $\begin{array}{c}\text { Post test Critical Thinking } \\
\text { Experiment Class (Elementery } \\
\text { Clarification) - Post test Critical } \\
\text { Thinking Control Class } \\
\text { (Elementery Clarification) }\end{array}$ & .50000 & 1.31937 & .24934 & -.01160 & 1.01160 & 2.005 & 27 & .055 \\
\hline 3 & $\begin{array}{l}\text { Post test Critical Thinking } \\
\text { Experiment Class (Basic Support) } \\
\text { - Post test Critical Thinking } \\
\text { Control Class (Basic Support) }\end{array}$ & .78571 & 1.10075 & .20802 & .35889 & 1.21254 & 3.777 & 27 & .001 \\
\hline
\end{tabular}




\begin{tabular}{|c|c|c|c|c|c|c|c|c|c|}
\hline 4 & $\begin{array}{c}\text { Post test Critical Thinking } \\
\text { Experiment Class (Inference) - } \\
\text { Post test Critical Thinking } \\
\text { Control Class (Inference) }\end{array}$ & 1.21429 & 1.06657 & .20156 & .80071 & 1.62786 & 6.024 & 27 & .000 \\
\hline 5 & $\begin{array}{c}\text { Post test Critical Thinking } \\
\text { Experiment Class (Advanced } \\
\text { Clarification) - Post test Critical } \\
\text { Thinking Control Class } \\
\text { (Advanced Clarification) }\end{array}$ & .85714 & 1.07890 & .20389 & .43879 & 1.27550 & 4.204 & 27 & .000 \\
\hline 6 & $\begin{array}{c}\text { Post test Critical Thinking } \\
\text { Experiment Class (Stategies and } \\
\text { Tactic) - Post test Critical } \\
\text { Thinking Control Class (Stategies } \\
\text { and Tactic) }\end{array}$ & 1.25000 & 1.07583 & .20331 & .83284 & 1.66716 & 6.148 & 27 & .000 \\
\hline
\end{tabular}

Based on the test results in Table 5, the critical thinking skills' average was higher on students who were performs guided inquiry learning than those who were conducted conventional learning, specifically in the aspects of basic support, inference, advanced clarification, strategies and tactic. Meanwhile, there was no difference in the elementary clarification aspects on students who perform guided inquiry learning and conventional learning.

Guided inquiry learning involves students designing their own observational activities to be carried out with the teacher's supervision, while the observation activities in the control class that apply conventional learning were designed by the teacher. Guided inquiry provides freedom for the students to express their ideas, answer the questions provided, and propose suggestions for problem-solving. Peter (2012) stated that learning that supports the improvement of critical thinking skills is to provide direction to students to analyze, synthesize, and evaluate information to solve problems and make decisions.

Guided inquiry learning, trains students to discover facts, data to be analyzed, provide ideas or arguments against the data obtained, explore information from various sources, answer questions or make conclusions, and communicate the results of their observations to stimulate their critical thinking skills. This means that guided inquiry learning trains and develops students' critical thinking skills. According to Stobaugh (2013), students that think critically are able to make decisions based on facts, analyze situations, evaluate arguments, and draw appropriate conclusions. The skills of analyzing, synthesizing, making connections between information, and argumentation are a set of critical thinking competencies that students need to possess (Rosen \& Maryam, 2014). Guided inquiry learning trains students to think of solving problems they face by analyzing, synthesizing, and evaluating information in order to make decisions.

However, the empirical evidence on the effectiveness of inculcating students' critical thinking skills was inconsistent, with learning that is able/unable to develop their critical thinking skills. The results of Bensley and Spero's (2014) research showed that critical thinking skills are developed through learning activities. Furthermore, Abrami et al. (2015) stated that the measurement of critical thinking skills is based on the subject matter. Devies (2013) also showed that critical thinking skills are developed through learning activities. This research is in line with the study that showed that critical thinking skills are developed through guided inquiry learning.

Furthermore, critical Thinking is empowered through assignments that require students to provide reasons, as well as evidence or logical arguments to support assessments, choices, claims, or statements (Fisher et al., 2009; Rosen \& Maryam, 2014). The habit of developing critical thinking skills in the learning provided by the teacher is expected to be beneficial for students and make it easier for them to determine solutions to the problems they face. It is used as basic or intellectual capital, which is very important for everyone and shows one's level of maturity (Mahanal, 2009).

\section{Conclusion}

In conclusion, the implementation of guided inquiry learning models tends to significantly improve the understanding of static fluid concepts and critical thinking skills of Vocational High School students compared to conventional learning. This is because it provides opportunities for students to independently construct concepts through presenting problems, hypotheses formulation, data, collection, and analysis, as well as making conclusions. However, the limited number of samples and the application of guided inquiry learning model only to the concept of static fluids were found as the weaknesses of this study. Hence, performing in large number of samples and applying several physical concepts, such as cinematic and dynamic, is suggested for further research. 


\section{Acknowledgments}

My thanks are due to Universitas Pendidikan Indonesia and the Director of Research and Community Service, Directorate General of Research and Development Reinforcement, Ministry of Research, Technology, and Higher Education of the Republic of Indonesia, who have granted funds for this research.

\section{References}

Abrami, P. C., Bernard, R. M., Borokhovski, E., Waddington, D. I., Wade, C. A., \& Persson, T. (2015). Strategies for teaching students to think critically: A meta-analysis. Review of Educational Research, 85(2), 275-314. https://doi.org/10.3102/0034654314551063

Adamčíková, V., \& Tarábek, P. (2010). Educational Communication and Curriculum Process in Physics Education.

Alonso, M., \& Finn E. J. (1992). Fundamental University Physics. Addison-Wesley.

Anderson, L. W., \& Krathwohl, D. R. (2001). A Taxonomy for Learning, Teaching, and Assessing: A Revision of Bloom's Taxonomy of Educational Objectives. New York: Longman.

Bensley, D., \& Spero, R. (2014). Improving Critical Thinking Skills and Metacognitive Monitoring Through Direct Infusion. Thinking Skills and Creativity, 12, 55-68. https://doi.org/10.1016/j.tsc.2014.02.001

Costa, A. L. (1985). Goals for a Critical Thinking Curriculum. In A. L. Costa (Ed.), Developing Mind: A Resource Book for Teaching Thinking. ASCD: Alexandria, Virginia.

Crawford, B. A. (2007). Learning to Teach Science as Inquiry in the Rough and Tumble of Practice. Journal of Research in Science Teaching, 44(4), 613-642. https://doi.org/10.1002/tea.20157

Dahar, R. W. (1996). Teori-teori Belajar. Bandung: Alfabeta.

Davies, M. (2013). Critical Thinking and The Disciplines Reconsidered. Higher Education Research \& Development, 32(4), 529-544. https://doi.org/10.1080/07294360.2012.697878

Ennis, R. H. (1985). Curriculum for Critical Thinking. In A. L. Costa (Ed.), Developing Mind: A Resource Book for Teaching Thinking. ASCD: Alexandria, Virginia.

Ennis, R. H. (1989). Critical Thinking and Subject Specificity: Clarification and Needed Research. Educational Researcher, 18(3), 4-10. https://doi.org/10.3102/0013189X018003004

Fang, S. C., Hsu, Y. S., Chang, H. Y., Chang, W. H., Wu, H. K., \& Chen, C. M. (2016). Investigating the Effects of Structured and Guided Inquiry on Students' Development of Conceptual Knowledge and Inquiry Abilities: A Case Study in Taiwan. International Journal of Science Education, 38(12), 1945-1971. https://doi.org/10.1080/09500693.2016.1220688

Fisher, R. (2007). Teaching Children to Learn. Google Books. United Kingdom: Stanley Thomas (Publisher) Ltd.

Frankel, J. R., \& Wallen, N. E. (2007). How to Design and Evaluate Research in Education (6th ed.). New York: MeGraw-Hill Book Co.

Gulo. (2008). Strategi Belajar-Mengajar. Jakarta: PT Grasindo.

Hake, R. R. (1998). Interactive - Engagement Versus Traditional Methods: A Six - Thousand - Student Survey of Mechanics Test Data for Introductory Physics Courses. American Journal of Physics, 66(1), 64-74. https://doi.org/10.1119/1.18809

Jauhar, M. (2011). Implementasi Paikem dari Behavioristik sampai Kontruktivistik. Jakarta: Prestasi Pustaka Publiser.

Johnson, D. W. (2000). Cooperative Learning and Social Interdependence Theory.

Joyce, B., Weil, M., \& Calhoun, E. (2000). Models of Teaching. USA: Alyn and Bacon.

Kalman, C. S. (2002). Developing Critical Thinking in Undergraduate Courses: A Philosophical Approach. Science \& Education, 11, 83-94. https://doi.org/10.1023/A:1013071130538

Kemendikbud. (2015). Materi Pelatihan Guru Implementasi Kurikulum 2013 Pelajaran Fisika SMA/SMK. Jakarta: Kemendikbud.

Kuhlthau, C. C., Maniotes, L. K., \& Caspari, A. K. (2007). Guided Inquiry: Learning in the 21st Century. Santa Barbara, CA: Libraries Unlimited. 
Maguire, L., Myerowitz, L., \& Sampson, V. (2010). Exploring Osmosis \& Diffusion in Cells. The Science Teacher, 77(8), 55.

Mahanal, S. (2009). Pengaruh Penerapan Perangkat Pembelajaran Deteksi Kualitas Sungai dengan Indikator Biologi Berbasis Proyek terhadap Hasil Belajar Siswa SMA di Kota Malang (Disertasi tidak diterbitkan). Pascasarjana Universitas Negeri Malang, Malang.

Marwiah. (2014). Penggunaan Conceptual Change Model Berbantuan Media Simulasi Virtual untuk Menurunkan Kuantitas Siswa yang Miskonsepsi dan Meningkatkan Pemahaman Konsep Siswa SMK Pada Materi Fluida Statis. Tesis Sekolah Pascasarjana Universitas Pendidikan Indonesia.

Minner, D. D., Levy, A. J., \& Century, J. (2010). Inquiry-Based Science Instruction - What is it and does it matter? results from a research synthesis years 1984 to 2002. Journal of Research in Science Teaching, 47(4), 474-496. https://doi.org/10.1002/tea.20347

National Research Council. (2012). A Framework for K-12 Science Education. Washington, DC: The National Academies Press.

Novak, J. D., \& Gowin, D. B. (1985). Learning how to Learn. New York: Cambridge University Press. https://doi.org/10.1017/CBO9781139173469

Ozdilek \& Bulunuz (2009). The Effect of a Guided Inquiry Method on Pre-Service Teachers' Science Teaching Self-Efficacy Beliefs. Journal of Turkish Science Education, 6(2), 24-42.

Peter, E. E. (2012). Critical Thinking: Essence for Teaching Mathematics and Mathematics Problem Solving Skills. African Journal of Mathematics and Computer Science Research, 5(3), 39-43. https://doi.org/10.5897/AJMCSR11.161

Putri, F. S., \& Istiyono, E. (2017). The Development of Performance Assessment of Stem-Based Critical Thinking Skill in the High School Physics Lessons. International Journal of Environmental \& Science Education, 12(5), 1269-1281.

Redish, E. F., Saul, J. M., \& Steinberg, R. N. (1998). Student expectations in introductory physics. American Journal of Physics, 66(3), 212-224. https://doi.org/10.1119/1.18847

Rosen, Y., \& Maryam, T. (2014). Making Student Thinking Visible Through a Concept Map in Computer-Based Assessment of Critical Thinking. Journal Educational Computing Research, 50(2), 249-270. https://doi.org/10.2190/EC.50.2.f

Sahin, M. (2010). Effects of problem-based learning on university students' epistemological beliefs about physics and physics learning and conceptual understanding of Newtonian mechanics. Journal of Science Education and Technology, 19(3), 266-275. https://doi.org/10.1007/s10956-009-9198-7

Sears, F. W., \& Zemansky, M. W. (2004). University Physics (10th ed.). Addison Wesley Publishing Company, Massachesetts.

Sopamena, O. (2009). Model Pembelajaran Inkuiri Terbimbing untuk Meningkatkan Pemahaman Konsep dan Keterampilan Proses Sains Siswa SMK pada Konsep Hasil Kelarutan. Tesis Universitas Pendidikan Indonesia: Tidak diterbitkan.

Spiro, M. D., \& Knisely, K. I. (2008). Alternation of Generations and Experimental Design: A Guided-Inquiry Lab Exploring the Nature of the Developmental Mutant of Ceratopteris richardii (C-Fem). Journal of life Sciences, 7, 201-207. https://doi.org/10.1187/cbe.07-82-88

Stobaugh, R. (2013). Assessing Critical Thinking in Middle and High Schools. New York: Routledge. https://doi.org/10.4324/9781315853451

Sund, R. B., \& Trowbridge, L. W. (1973). Teaching Science by Inquiry in the Secondary School (2nd ed.). London: Charles E. Merrill Publishing Company.

Suparno, P. (2013). Metodologi Pembelajaran Fisika (Konstruktivisme dan Menyenangkan). Yogyakarta: Universitas Sanata Dharma.

Thomas, G. P. (2013). Changing the Metacognitive Orientation of a Classroom Environment to Stimulate Metacognitive Reflection Regarding the Nature of Physics Learning. International Journal of Science Education, 35(7), 1183-1207. https://doi.org/10.1080/09500693.2013.778438

Tipler, P. A., \& Mosca, G. (2007). Physics for Scientists and Engineers. New York: W. H. Freeman.

Tiruneh, D. T., De Cock, M., Weldeslassie, A. G., Elen, J., \& Janssen, R. (2017). Measuring critical thinking in 
physics: Development and validation of a critical thinking test in electricity and magnetism. International Journal of Science and Mathematics Education, 15(4), 663-682. https://doi.org/10.1007/s10763-016-9723-0

Tiruneh, D. T., Weldeslassie, A. G., Kassa, A., Tefera, Z., De Cock, M., \& Elen, J. (2016). Systematic design of a learning environment for domain-specific and domain-general critical thinking skills. Educational Technology Research and Development, 64(3), 481-505. https://doi.org/10.1007/s11423-015-9417-2

Tseng, C. H., Tuan, H. L., \& Chin, C. C. (2013). How to help teachers develop inquiry teaching: Perspectives from experienced science teachers. Research in Science Education, 43(2), 809-825. https://doi.org/10.1007/s11165-012-9292-3

Verlinden, J. (2005). Critical Thinking and Every day Argument. Balmont, CA: Wadsworth/the msou learning, Inc.

Walker, G. H. (1998). Critical Thinking.

Wenning, C. J. (2011). Levels of Inquiry Model of Science Teaching. Journal Physics Teacher Education Online, $6(2)$.

Zohar, A. (1994). The Effect of Biology Critical Thinking Project in the Development of Critical Thinking. Journal of Research in Science Teaching, 31(2), 163-196.

Zoller, U., Ben-Chaim, D., Ron, S., Pentimalli, R., Scolastica, S., Chiara, M. S., \& Borsese, A. (2000). The disposition toward critical thinking of high school and university science students: an interintra Israeli-Italian Study. International Journal of Science Education, 22(6), 571-582. https://doi.org/10.1080/095006900289679

\section{Copyrights}

Copyright for this article is retained by the author(s), with first publication rights granted to the journal.

This is an open-access article distributed under the terms and conditions of the Creative Commons Attribution license (http://creativecommons.org/licenses/by/4.0/). 